\title{
Approaches for the Racial and Ethnic Determination of a Person
}

\author{
Shafagat Jabrail Mahmudova \\ Institute of Information Technology of ANAS, Baku, Az1141, Azerbaijan; \\ shafagat_57@mail.ru
}

\begin{abstract}
The article describes the approaches for the racial and ethnic determination of a person. Ethnic belonging of any person is one of his groups of signs; hence, the need for its study may be due to a variety of reasons, such as the recognition of a person's face, creating identification card, making up the image of an unknown person, or of a missing person or suspected criminals, and so on.
\end{abstract}

Keywords: Face, recognition, ethnic groups, criminals, determination

\section{Introduction}

Many professional areas of (customs, border control, security services, etc.) might be interested in the theoretical and practical studies on the racial and ethnic identification of a person. Solution of this issue may reduce the time spent for the search of millions of photos stored in the database during the recognition of a person on the basis of images, as well as decrease the scope of the search significantly.

A number of specialists of various affiliations are engaged in solving the problems of racial and ethnic determination of a person. Existing problems in this area are solved with the use of different methods.

The researchers specialized in the humanitarian field, such as Anthropology, Ethnography and Race studies, as well as other experts in the technical sciences, as Biometric technologies, Pattern recognition, Medicine, and so deal with the solution of the current problems.

Developed and tested methods of identification and evaluation of individual psychological characteristics of people of different racial groups by photographs of their faces [1].

Ethnography is originated from the combination of the Greek words"ethnos"(people), and"grafis"(to describe). The main objective of ethnography is to study the nations and to explore their history.

Some methods in the field of ethnography are:

- The method of value orientations by Rokich;

- Cognitive-communicative method;

- The method of "Who am I" by Kuna-Makpartlend;

- The method of stereotypes research;

- The method of "Writing additional qualities" by Stefanenko;

- Bipolar schedules for studying the dependence of the personal qualities on the nation, and so on.

Some trends in the field of Ethnography: 
- Primordialism. This approach assumes that the ethnic belonging of a person originates from the nature orthe society and exists objectively;

- Dual theory of ethnic groups;

- Social biological direction;

- Pierre Den BergheTheory;

- Passionate ethnos theory by Gumilev;

- Constructivism;

- Instrumentalism and others.

Anthropology (anthropos - human, logos - science) a natural science about a humanity. It studies the formation and development of the humanity, the emergence of human race, and the common changes in the physical structure of human is shown in Figure 1.

Anthropology is a field of science the subject of which is a human.

Race studies (or ethnic anthropology) the branch of anthropology that studies and explores the emergence origins of races, race types, its classification and distribution areas on the Earth, the compliance of the racial types with the changes [2,3].

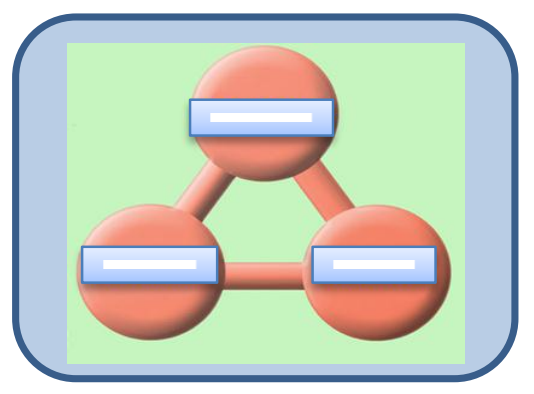

Figure 1. Social fields of the racial and ethnic determination of a human

The concept of race was first used in 1684 by French ethnographer and traveler Francois Berne.

Race is a group of people who formed in a certain geographic region and share similar genetic and distinct biological characteristics. The characteristic features of the various human races are possible as a result of adaptation to a certain environment.

In another source the race is defined as large groups of people differing by the physical features passed from generation to generation historically inhabited in a particular area.

A complex of physical signs have emerged as a result of the adaptation to the environment, due to which three main races of the peoples all over the world were distinguished: "white", "black" and "yellow", respectively europoid, mongoloid and. negroid Lately, it is recommended to distinguish an amerikanoid race from mongoloid race.

Ethnicity (Greek.'EOvos (ethnos) nation) isa historical complex of people having culture and psyche with relatively stable features, as well as of the people differing from others and speaking in own language.

Ethnogeny [Greek. ethnos - people and genesis - birth] is the origin of any nation [4].

\section{Some Problems of Racial or Ethnic Determination of a Person}

Some problems of racial or ethnic determination of a person:

1. According to the bones of the skull; 
2. According to the face images;

3. According to the finger and palm patterns;

4. According to eye;

5. According to teeth and so on. (is shown in Figure 2).
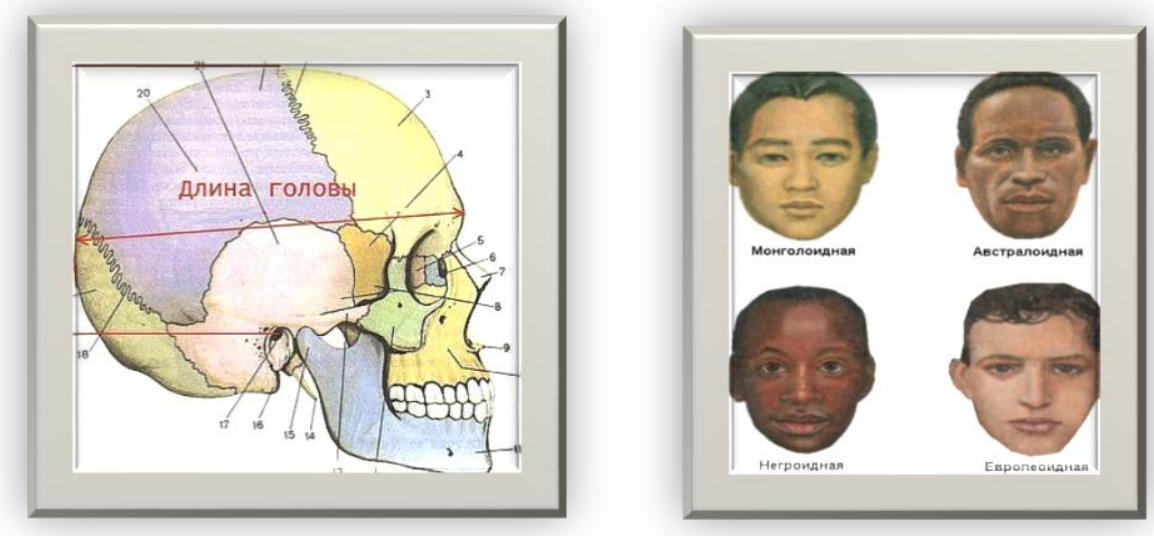

According to the bones of the skull

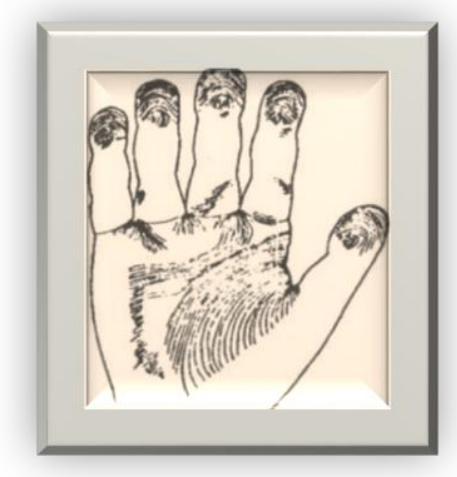

According to the fingerprint patterns

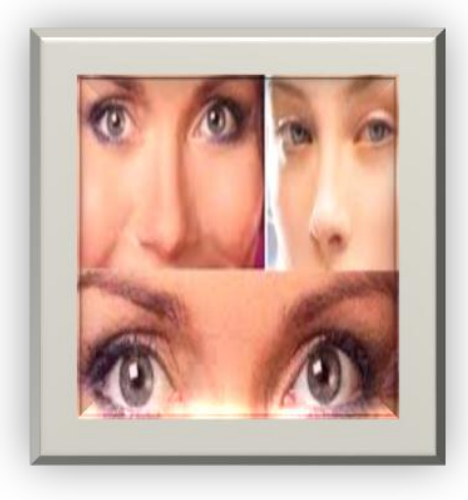

According to the eyes

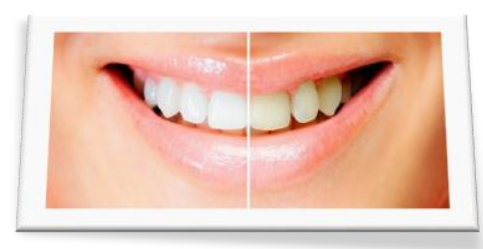

According to teeth

Figure 2

- Racial or ethnic determination of a person according to the bones of the skull (the bones of the skull is the object of the study):

- Problem solving and conducting experiments according to the given methods;

- Measuring the indicators;

- Comparison with the figures in the table;

- Determination of the race [5].

- Racial or ethnic determination of the race. of a person according to the face images.

In some issues the following features of a human face are used (is shown in Figure 3):

- The height of the forehead the upper part of the nose;

- The distance between the inner and outer corners of the eyes;

- The distance from the tip of the nose to the chin;

- The width of the nose;

- The distance from the top of the nose to the tip of the nose;

- The distance from the tip of the nose to the center of the lips [6]. 
Among different approaches for 3D face recognition, solutions based on local facial characteristics are very promising. However, so far, a few works have investigated the individual relevance that local features play in 3D face recognition.

The proposed solution is experimented using facial scans of the Face Recognition Grand Challenge dataset [7].

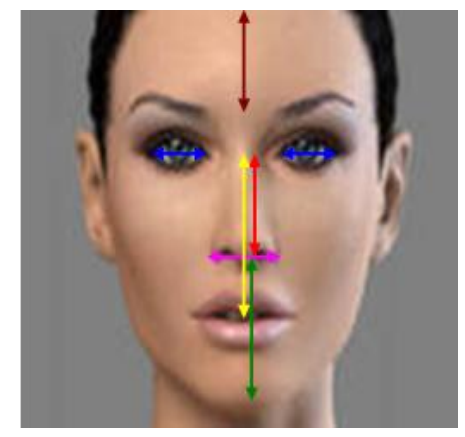

Figure 3. Some signs of the human face image

Racial or ethnic identification of a person according to the finger and palm patterns

Dermatoglyphics (from ancient Greek word $\Delta \varepsilon \dot{\varepsilon} \rho \alpha \alpha$, (b P. $\Delta \varepsilon \dot{\varepsilon} \rho \alpha \tau$ to - skin and $\gamma \lambda u ́ \phi \omega$-carving)studies the skin patterns of the palms and soles of a person.

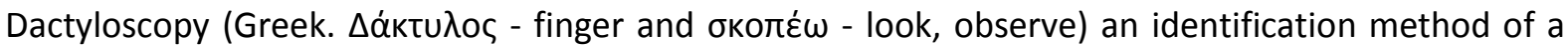
person according to the finger prints on the skin, and relies on the patterns observed in individual prints (is shown in Figure 4).

Currently, the most common applications characterize the papillary patterns of the fingertips [8].
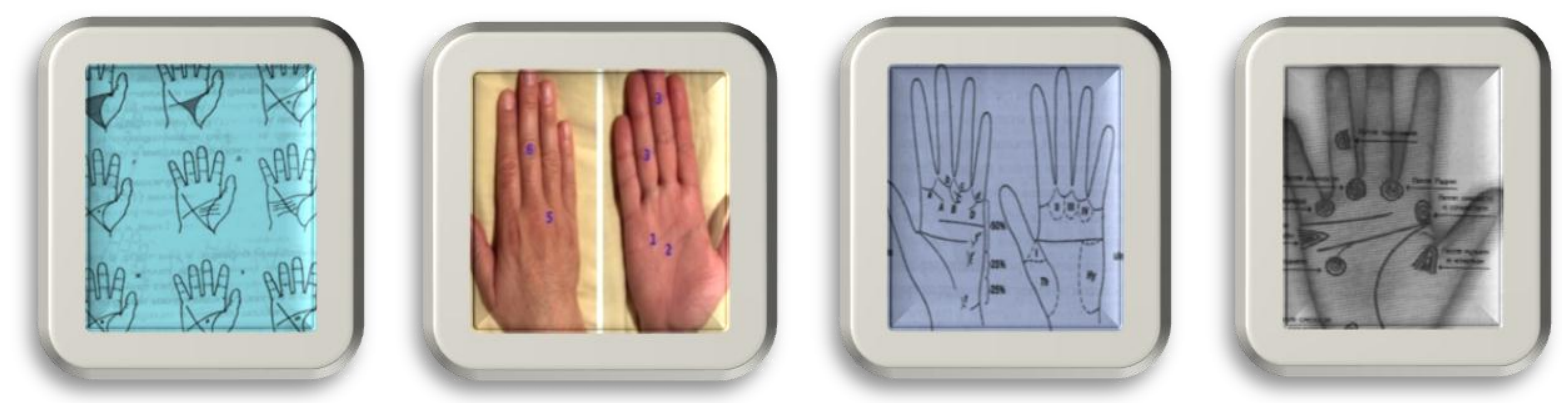

Figure 4. Racial or ethnic determination of a person according to the eyes

Gustav Fritsch (1839-1891) first showed the racial differences of the cellular retina of the eyes [9]. The cellular retina is a thin nerve membrane of the front side of the back wall of eyeball (is shown in Figure 5). 

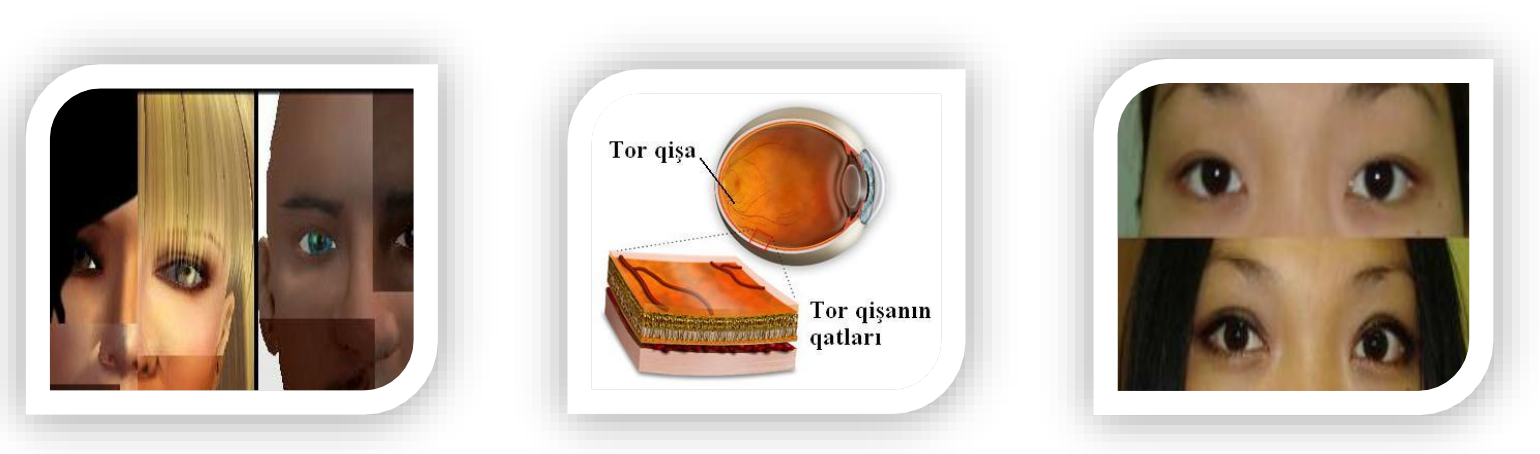

Figure 5. Racial or ethnic determination of a person according to the teeth

Dental identification determines a person's racial and ethnic identity according to his teeth.

The teeth of each individual has the unique characteristics. The mandible, where the teeth are located, is also used here [10].

\section{Human Face Determination according to the Racial Features}

As the human face is the source of most of information signals, it is supposed that in the east, they could predict a person's life according to his face. A person's face is the center of the human behavior and communication, and it has a capacity.As a rule,the face is described in two projections:

- En face;

- Profile.

According to the human face the age, sex and ethnic origin and race can be identified.

Scientists have used a variety of methods for the racial or ethnic determination of a person according to his face. As a result, it has been suggested that the person belongs to one of the three races europoid, mongoloid and negroid according to the geometric signs of the face. In these cases, 11 points of a person's face are used. Diverse methods have been applied for the human face recognition according to these points [11].

In other identification issues certain parameters of the human face image were set. The work targeted at the racial identification of the person according to his front side (en face) image.

The survey revealed that the proportion of the head, the width of the mandible, the shape of the nose and lips, the edge of the eyes and so on are the main parameters. Relative parameters should be used in order to work with these criteria:

- Proportionality of the head - the correlation of the width of the face to its height ( 3 points)

- The correlation of the width of the forehead to the width of the mandible ( 2 points)

- The correlation of the width of the nose to the width of the mandible ( 2 points)

- The correlation of the width of the lips to the width of the mandible ( 3 points)

- The correlation of the width of the eyes to their height ( 3 points)

The standard descriptions of the representatives of the races are stored in the database according to the developed methods. The points of the parameters are used for the determination of some races. If the initial parameters are similar to the standards, then the scores are recorded. All parameters area analyzed, the most identical face parameters of any race are defined [12]. 


\section{Results}

Research works are carried out in this field at the Institute of Information Technology of ANAS.

The study examines the racial and ethnic identification of a person according to his face image. The standard images are developed according to the certain geometric points of the face and the special algorithm for the calculating of the certain parameters of the images stored in the database (is shown in Figure 6). Then, the initial image is compared to the images of various ethnic groups stored in the database, and thus, the racial and ethnic identification of the person is defined [13-14].
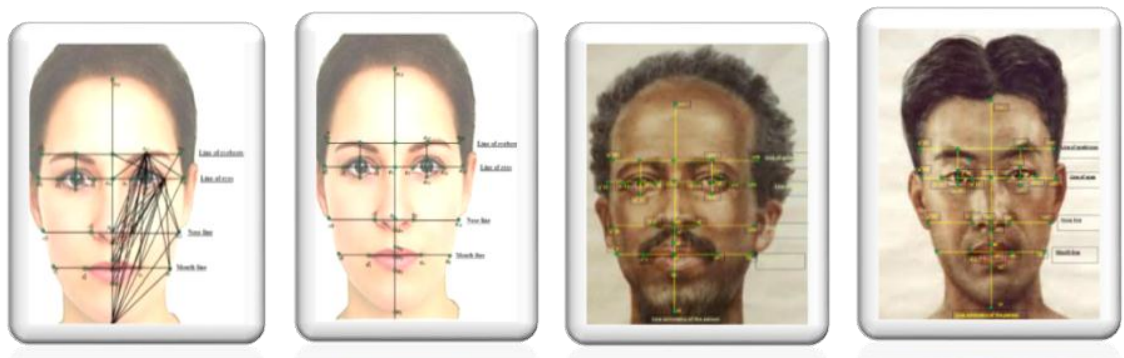

Figure 6. Standard images

\section{REFERENCES}

[1] Барабанщиков В. А., Ананьева К.И. Восприятие фотоизображений лиц людей разной расовой принадлежности // Вестник РУДН, 2009, № 1, с. 7-13.

[2] http://az.wikipedia.org/wiki/\%C4\%BOrq

[3] http://az.wikipedia.org/wiki/Etnoqrafiya

[4] http://az.wikipedia.org/wiki/Etnos

[5] Звягин В.Н. “Определение расовой принадлежности по костям черепа", Судебномедицинский центр М3 РФ. (http://www.expertkriminalist.ru/info/pasportametodik/medkrimpasport/medkrim1/)

[6] http://www.dmitriyo.ru/

[7] Alberto Del Bimbo, Pietro Pala, Stefano Berretti. Distinguishing Facial Features for EthnicityBased 3D Face Recognition // ACM Transactions on Intelligent Systems and Technology (TIST), 2012, pp. 1-20.

[8] Хить Г. Л., Долинова Н. А. Расовая дифференциация человечества (Дерматоглифические данные) / Ин-т этнографии им. Н.Н. Миклухо-Маклая.-М.:Наука, 1990,

http://polbu.ru/avdeev_rasologiya/ch25_all.html

[9] http://www.medical-enc.ru/sudmed/identification-trupov-3.shtml 
[10] Л.Р.Адылова, “О распознавании лич”, Интеллектуальные системы, Москва, 2010, том.14, стр. 73-84.

[11] T. H.Kazımov, Sh.J Mahmudova. About a Method of Calculation of Importance Degree of Geometrical Characteristics to Identify a Human Face on the Basis of Photo Portraits // Computer Science and Engineering, 2012, Vol. 2, No. 5, USA, pp. 59-62.

[12] http://habrahabr.ru/post/139745/

[13] T. H.Kazımov, Sh.J Mahmudova. About A Method of Calculation of Importance Degree of Geometrical Characteristics to Identify a Human Face On The Basis Of Photo Portraits / Proceedings of the 7 th IAPR International Conference on Pattern Recognition in Bioinformatics, November 8-10, 2012, Tokyo, pp. 154-160.

[14] T. H.Kazımov, Sh.J Mahmudova. Increase of indicator values of identification systems quality on the recognition of human face on the basis of photoportraits // Intelligent Control and Automation, 2013, Vol. 4, No. 2, USA, pp. 191-198. 